\title{
Cellular Effects of the Antiepileptic Drug Valproic Acid in Glioblastoma
}

\author{
Marita Eckert ${ }^{\mathrm{a}}$ Lukas Klumppa ${ }^{\mathrm{a}, \mathrm{b}}$ Stephan M. Huber \\ aDepartment of Radiation Oncology, University of Tübingen, ${ }^{b} D r$. Margarete Fischer-Bosch-Institute of \\ Clinical Pharmacology, Stuttgart, Germany
}

\section{Key Words}

Glioma - Radiation therapy - Radioresistance - Fura-2 $\mathrm{Ca}^{2+}$ imaging - Transfilter migration • Chemotaxis $\cdot \mathrm{Ca}^{2+}$-activated potassium channel $\cdot \mathrm{KCNMA1}$, primary glioblastoma spheroids $\cdot$ Temozolomide • O-6-methylguanine-DNA methyltransferase (MGMT) • Histone deacetylase (HDAC)

\begin{abstract}
Background/Aims: Valproic acid (VPA), an anticonvulsant and mood-stabilizing drug is used to treat epileptic seizure of glioblastoma patients. Besides its antiepileptic activity, VPA has been attributed further functions that improve the clinical outcome of glioblastoma patients. Those comprise the inhibition of some histone deacetylase (HDAC) isoforms which reportedly may result in radiosensitization. Retrospective analysis of patient data, however, could not unequivocally confirm a prolonged survival of glioblastoma patients receiving VPA. The present study aimed to identify potential VPA targets at the cellular level. Methods: To this end, the effect of VPA on metabolism, $\mathrm{Ca}^{2+}$, biochemical and electro-signaling, cell-cycling, clonogenic survival and transfilter migration was analyzed in three human glioblastoma lines (T98G, U-87MG, U251) by MTT assay, $\mathrm{Ca}^{2+}$ imaging, immunoblotting, patch-clamp recording, flow cytometry, delayed plating colony formation and modified Boyden chamber assays, respectively. In addition, the effect of VPA on clonogenic survival of primary glioblastoma spheroid cultures treated with temozolomide and fractionated radiation was assessed by limited dilution assay. Results: In 2 of 3 glioblastoma lines, clinical relevant concentrations of VPA slightly slowed down cell cycle progression and decreased clonogenic survival. Furthermore, VPA induced $\mathrm{Ca}^{2+}$ signaling which was accompanied by pronounced $\mathrm{K}^{+}$channel activity and transfilter cell migration. VPA did not affect metabolic $N A D(P) H$ formation or radioresistance of the glioblastoma lines. Finally, VPA did not impair clonogenic survival or radioresistance of temozolomide-treated primary spheroid cultures. Conclusions: Combined, our in vitro data do not propose a general use of VPA as a radiosensitizer in anti-glioblastoma therapy.
\end{abstract}




\section{Introduction}

The standard therapy for glioblastoma multiforme patients consist of surgical resection followed by radiation therapy and concomitant chemotherapy with temozolomide, an alkylating agent that methylates DNA and that is most effective in glioblastomas with methylated promotor of the 0-6-methylguanine-DNA methyltransferase (MGMT) gene [1, $2]$. Therapy failure observed in the vast majority of glioblastoma patients and bad prognosis are probably due to a high intrinsic resistance to chemo- and radiotherapy on the one hand and on the fast spreading of glioblastoma cells in the brain on the other. Up to $50 \%$ of glioblastoma patients develop tumor-associated epileptic seizures that are treated with antiepileptic drugs such as valproic acid (VPA) [3]. In the human brain, VPA potentates the inhibitory activity of the neurotransmitter GABA, attenuates NMDA receptor-mediated excitation, and may block voltage-gated $\mathrm{Na}^{+}-\mathrm{Ca}^{2+}-$, and $\mathrm{K}^{+}$channels (for review see $[4,5]$ ).

In addition to its anticonvulsive action, VPA has been demonstrated to inhibit histone deacetylases (HDAC, for review see [6]) suggesting that histone hyperacetylation might occur during VPA therapy and might contribute to the anticonvulsive VPA effect. Along those lines, the VPA-induced histone hyperacetylation has been proposed to contribute to teratogenic side effects of VPA [7] possibly together with the VPA action as antimetabolite to folic acid and VPA-induced oxidative stress [8].

Histone deacetylase inhibitors have been demonstrated to modify chromatin structure, gene expression, and to radiosensitize tumor cells [9]. As a matter of fact, VPA-mediated radiosensitization of glioblastoma cells has been observed in vitro and in preclinical in vivo studies [10-15].VPA-mediated HDAC inhibition has been demonstrated to induce replicationindependent active DNA demethylation [16]. DNA demethylation, however, might induce upregulation of MGMT expression and might confer resistance to temozolomide. In contrast to this assumption, VPA has been shown to down-regulate MGMT expression in glioma cells [17] and to sensitize glioblastoma cells to temozolomide in vitro in some $[11,17,18]$ but not all [19] studies (for review see [20].

Beyond radio- and temozolomide sensitization, VPA-mediated histone hyperacetylation and DNA demethylation are associated with changes in cell morphology, decrease cell viability and increase apoptosis rates [14, 19, 21, 22]. Moreover, VPA treatment of glioma cells has been demonstrated to boost the adaptive immune response. Vaccination with VPAtreated glioma cells, however, did not improve mouse survival in syngeneic glioma mouse models [23]

In accordance with these results, retrospective (meta-)analysis [24-30] of patient data and a single-armed phase-2 clinical trial [31] suggested prolonged survival of glioblastoma patients receiving VPA. A meta study analyzing the largest cohort (1,800 patients), in sharp contrast, could not confirm that VPA treatment of newly diagnosed glioblastoma patients associates with longer progression-free and overall survival [32]. A further multivariate analysis of 647 patients with de novo glioblastoma identified epilepsy as a prognostic factor for longer survival. Epileptogenic tumors exhibited significantly smaller volumes than those of non-epileptogenic ones probably due to earlier detection [33]. Nevertheless, epilepsy cannot be attributed solely to early diagnosis since it was associated with better prognosis independently of tumor volume in multivariate analysis. In glioblastoma patients presenting with epilepsy, however, VPA treatment did not associate with survival [33] again challenging the value of VPA in anti-glioblastoma therapy. The conclusiveness of these studies is debated since they are retrospective in nature with limited correction for confounders, and the dosages and duration of VPA treatment were often not defined [34]. Moreover, some the studies have low statistical power due to small patient cohorts or leave epilepsy as prognostic factor per se out of consideration. [33].

Combined, these conflicting results do not allow to define conclusively the benefit (besides its anticonvulsive action) of VPA for anti-glioblastoma therapy. The present study, therefore, aimed to collect further data on the effect of VPA in glioblastoma at a cellular level by analyzing VPA-induced modification of signaling, physiology and radiation biology.

\section{KARGER}




\section{Cellular Physiology Cell Physiol Biochem 2017;44:1591-1605

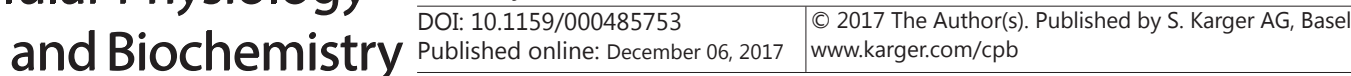 \\ Eckert et al.: VPA in Glioma}

\section{Material and Methods}

Human glioblastoma cell lines T98G and U-87MG were grown in RPMI-1640, human U251 glioblastoma cells in DMEM (4.5 g glucose/l). Both media were supplemented with 10\% fetal bovine serum (FBS). All experiments with these cell lines were performed with exponentially growing cultures. For primary spheroid cultures, resected glioblastoma tissue (patients gave informed consent and this study has been approved by the local ethic committee under project\# 579/2015B02) was dissociated enzymatically and mechanically and plated in Complete NeuroCult ${ }^{\mathrm{TM}} \mathrm{NS}-\mathrm{A}$ Proliferation medium containing $20 \mathrm{ng} / \mathrm{ml} \mathrm{rh} \mathrm{EGF}$, $10 \mathrm{ng} / \mathrm{ml} \mathrm{rh}$ bFGF and 0.0002\% heparin (STEMCELL Technologies Germany GmbH, Cologne, Germany). Tumor specimens (LK-XI, LK-XII, and LK-XIII) from two male and a female patient (72-74 years old) with according to the pathology report confirmed grade IV astrocytoma (glioblastoma) and wildtype isocitrate dehydrogenase-I status were used. In one of these specimens (specimen LK-XII) the 0-6-methylguanineDNA methyltransferase (MGMT) gene was downregulated epigenetically, not so in the other two specimens. Every second day, 1/10 of the original medium volume of the primary spheroid culture was replenished. Valproic acid (VPA, Sigma, Deisenhofen, Germany) was prepared in $100 \mathrm{mM}$ stock solution in the respective media or $\mathrm{NaCl}$ solution (125 mM NaCl, $32 \mathrm{mM}$ Hepes/NaOH, pH 7.4, $5 \mathrm{mM} \mathrm{KCl,} 5 \mathrm{mM}$ D-glucose, $1 \mathrm{mM}$ $\mathrm{CaCl}_{2}, 1 \mathrm{mM} \mathrm{MgCl}_{2}$ ). A $10 \mathrm{mM}$ and a $100 \mathrm{mM}$ stock solution of paxilline and temozolomide (both Sigma), respectively, were prepared in DMSO.

To analyze the effect of VPA treatment on metabolism, exponential growing T98G, U251 and U-87MG cells (750 cells/well) were treated for $48 \mathrm{~h}$ with 0-1000 $\mu \mathrm{M}$ VPA. Thereafter, 3-[4,5-dimethylthiazol-2-yl]-2,5diphenyltetrazolium bromide (MTT, Sigma) transformation to formazane was determined photometrically as a measure of metabolic NAD(P)H turnover.

Fura-2 $\mathrm{Ca}^{2+}$ imaging was performed as described [35] in U251 cells superfused with NaCl solution before, during, and after administration of VPA $(750 \mu \mathrm{M})$. Immunoblotting of VPA ( 0 or $750 \mu \mathrm{M}$ for $48 \mathrm{~h})$ treated U251 cells was carried out according to [36] with the following antibodies: anti-cdc25A (\#3652S, Cell Signaling, Danvers, USA), anti-p(S124)-cdc25A (\#T1155, epitomics, Burlingame, USA), anti-cdc25B (\#9525S Cell Signaling), anti-p(Ser187)-cdc25B (\#T1162, epitomics), anti-cdc25C (\#4688S, Cell Signaling), p(S216)-cdc25C (\#4901S, Cell Signaling), cdc2 (\#9112S, Cell Signaling) and p(Tyr15)-cdc2 (\#9111S, Cell Signaling, all 1:500) and anti- $\beta$-actin (clone AC-74, \#A2228, Sigma, 1: 20.000).

Cell cycle distribution (after $48 \mathrm{~h}$ and $72 \mathrm{~h}$ treatment with 0, 250 or $750 \mu \mathrm{M} \mathrm{VPA}$ ) of T98G, U251 and U-87MG cells and clonogenic survival (after $1 \mathrm{~h}$ pre-incubation, irradiation with 0, 2, 4, or 6 Gy 6 MV, and $24 \mathrm{~h}$ post-incubation all in the presence of 0 and $750 \mu \mathrm{M}$ VPA, respectively) were determined by flow cytometry and delayed plating colony formation assay, respectively, essentially as described [37]. VPA (0 or $750 \mu \mathrm{M}$ )-stimulated ion channel activity and transfilter chemotaxis were assessed in T98G and U251 cells by patch-clamp on-cell recording (using $\mathrm{NaCl}$ solution in bath and pipette) and real-time impedance recording (xCELLigence system, Roche, Mannheim, Germany), respectively, essentially as described [37].

To determine clonogenic survival of primary glioblastoma by limited dilution assay, spheroids were dissected mechanically into single cells and 2500 cells were sequentially 1:2-diluted. Dilution were performed in $100 \mu \mathrm{l}$ Complete NeuroCult ${ }^{\mathrm{TM}}$ NS-A Proliferation medium (STEMCELL Technologies Germany $\mathrm{GmbH}$, Cologne, Germany) additionally containing temozolomide (5 $\mu \mathrm{M}$ in $0.005 \%$ DMSO) and VPA (0 or $750 \mu \mathrm{M})$. Starting $1 \mathrm{~h}$ after sequential dilution and onset of temozolomide and VPA treatment, cells were fractionated irradiated applying a total dose of 0 or 10 Gy (6 MV photons) in 5 fractions of 2 Gy on 5 consecutive days. After further 6 week of incubation in the presence of temozolomide $(5 \mu \mathrm{M})$ and VPA (0 or $750 \mu \mathrm{M}$ ) minimal cell number required to sustain the primary culture was determined as a measure of clonogenic survival.

Data are means \pm SE and statistical analysis was made by normal or Welch-corrected two-tailed unpaired or paired t-test, parametric ANOVA using Tukey's post hoc test, or Kruskal-Wallis test (nonparametric ANOVA) where appropriate. ${ }^{*}, * *$, and ${ }^{* * *}$ indicate $\mathrm{p} \leq 0.05,0.01$ and 0.001 , respectively.

\section{Results}

The effects of valproic acid (VPA) on metabolic rate, $\mathrm{Ca}^{2+}$ and biochemical signaling, cell cycle control, clonogenic survival, ion channel activity, and cell motility were studied 
in the glioblastoma cell lines T98G, U251 and U-87MG. To define the effect of VPA on metabolic NAD(P)H formation, MTT dehydrogenase activity was measured in the presence of increasing concentrations of VPA $(100 \mu \mathrm{M}-1 \mathrm{mM})$. In all three glioblastoma cell lines, VPA inhibited MTT dehydrogenase activity at concentrations $\geq 800 \mu \mathrm{M}$ with apparent $\mathrm{IC}_{50}$ of 1.4 , 1.0, and $1.3 \mathrm{mM}$ in T98G, U251 and U-87MG cells, respectively (Fig. 1).

To test for VPA-triggered signaling events, cytosolic free $\mathrm{Ca}^{2+}$ concentration was measured in all three glioblastoma cell lines by fura- $2 \mathrm{Ca}^{2+}$ imaging before, during acute administration and upon wash-out of VPA $(750 \mu \mathrm{M})$. As shown in Fig. 2A, B, VPA stimulated a prominent long-lasting increase in intracellular free $\mathrm{Ca}^{2+}$ concentration in U251 cells. In U-87MG cells, in contrast, VPA evoked only a minute but significant $(\mathrm{p} \leq 0.001) \mathrm{Ca}^{2+}$ increase (fura-2 fluorescence ratio increased from 0.63 to $0.64, n=136)$ while in T98G cells $(n=126)$ VPA did not exert any apparent effect (data not shown).

In glioblastoma cells, isoforms of the $\mathrm{Ca}^{2+} /$ calmodulin-dependent kinase-II (CaMKII) have been identified as downstream targets of $\mathrm{Ca}^{2+}$ and $\mathrm{Ca}^{2+}$-activated $\mathrm{K}^{+}$channels [38]. CaMKII, in turn, has been reported to regulate the cell cycle via inactivation of cdc25 isoforms and subsequent inactivation of cdc2 (CDK1) [39-42]. To define putative $\mathrm{Ca}^{2+}$-mediated VPA effects on cell cycle, VPA (0 or $750 \mu \mathrm{M}$ for $48 \mathrm{~h}$ )-treated U251 cells were probed against cdc25A, $-\mathrm{B},-\mathrm{C}$ and cdc2 as well as against the phosphorylated forms of these proteins by immunoblotting. VPA did not alter abundances of total or phosphorylated cdc25B and -C (data not shown). In contrast, VPA stimulated phosphorylation of cdc25A (Fig. 2C-E) and accumulation of the phosphorylated and inactive form of cdc2 (Fig. 2F-H). Together, these experiments indicate that VPA may interfere with signaling and cell cycle regulation in glioblastoma cells.

Next, the effect of VPA $(0,250$ or $750 \mu \mathrm{M}$ for $48 \mathrm{~h}$ and $72 \mathrm{~h}$, respectively) on cell cycle was analyzed in flow cytometry experiments by determining the DNA content of permeabilized glioblastoma cells with the fluorescent dye propidium iodide (Fig. 3A). As a result, VPA did not modify cell cycling of T98G cells (Fig. 3A, left, and 3B, E). In U251, in contrast, VPA $(750 \mu \mathrm{M})$ significantly increased $\mathrm{S}(72 \mathrm{~h} \mathrm{VPA})$ and $\mathrm{G}_{2}$ population (48 $\mathrm{h}$ and $\left.72 \mathrm{~h} \mathrm{VPA}\right)$. The latter effect was also seen after $72 \mathrm{~h}$ treatment with the lower VPA dose (250 $\mu \mathrm{M}$, Fig. 3C, F). Similarly, in U-87MG cells VPA $(750 \mu \mathrm{M})$ significantly decreased $\mathrm{G}_{1}$ population (48 h VPA) and increased S (48 h and $72 \mathrm{~h} \mathrm{VPA}$ ) and $\mathrm{G}_{2}$ population (72 h VPA, Fig. 3A, right, and 3D, G). Together, this points to a VPA-induced $S$ and $\mathrm{G}_{2} / \mathrm{M}$ cell cycle arrest in U251 and U-87MG cells.

To determine, whether this VPA-mediated cell cycle interference might radioprotect or radiosensitize glioblastoma cells, colony formation was measured in all three glioblastoma cell lines upon irradiation (0, 2, 4 and 6 Gy 6 MV photons). Cells were pre-incubated (1h), irradiated and post-incubated $(24 \mathrm{~h})$ with VPA $(0$ or $750 \mu \mathrm{M})$ before plating the cells in VPA-

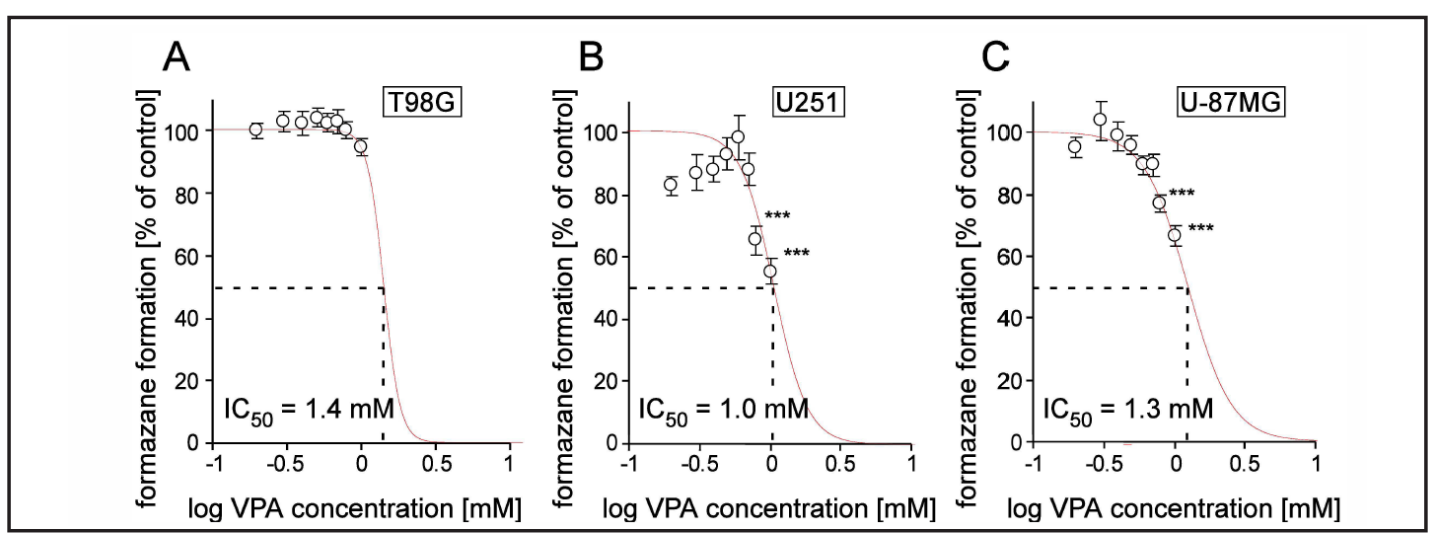

Fig. 1. Effect of valproic acid (VPA) on metabolism of human glioblastoma cell lines as determined by MTT assay. A, B, C. Mean formazan formation ( \pm SE of 3-5 experiments) of T98G (A), U251 (B) and U-87MG (C)

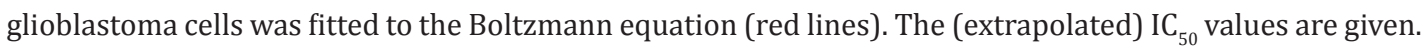
$* * *$ indicates $\mathrm{p} \leq 0.001$, ANOVA. 
Fig. 2. VPA triggers $\mathrm{Ca}^{2+}$ signaling in glioblastoma cells. A. Mean ( $\mathrm{n}=15$ ) fura-2 $340 / 380 \mathrm{~nm}$ fluorescence ratio in U251 cells as a measure of cytosolic free $\mathrm{Ca}^{2+}$ concentration before, during, and after application of VPA $(750 \mu \mathrm{M}$, closed triangles) or control solution (open circles). B. Mean ( $\mathrm{n}=$ 163) VPA $(750 \mu \mathrm{M})$-induced increase in fura-2 340/380 nm fluorescence ratio. $\mathrm{C}-\mathrm{H}$. Immoblots of VPA-treated ( 0 or $750 \mu \mathrm{M}$ for $48 \mathrm{~h})$ U251 cells probed against phospho-cdc25A and cdc25A (C) and against phospho-cdc2 and cdc2 (F) and for loading control against the $\beta$-actin $(C, F$, lower blot). D-E and G-H show the semiquantified mean ( $n=6$-9) $\beta$-actinnormalized protein abundances for phospho-cdc25A (D), cdc25A (E), phospho-cdc2 (G) and cdc2 (H) in control (open bars) and VPA-treated (closed bars) U251 cells.

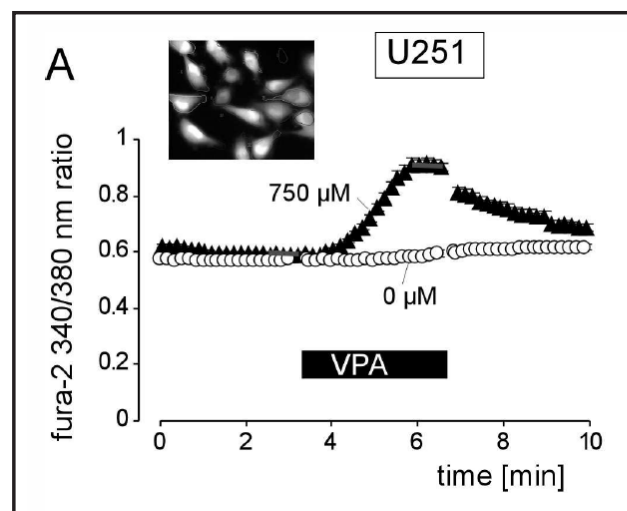

C

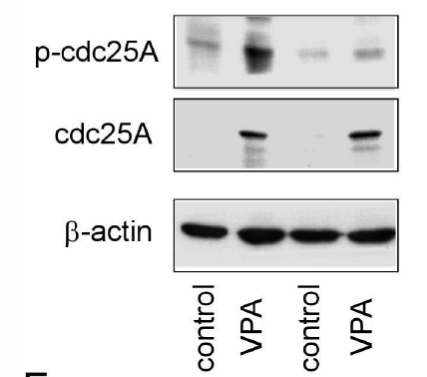

F
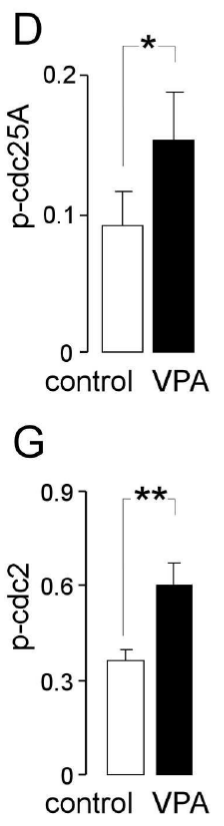
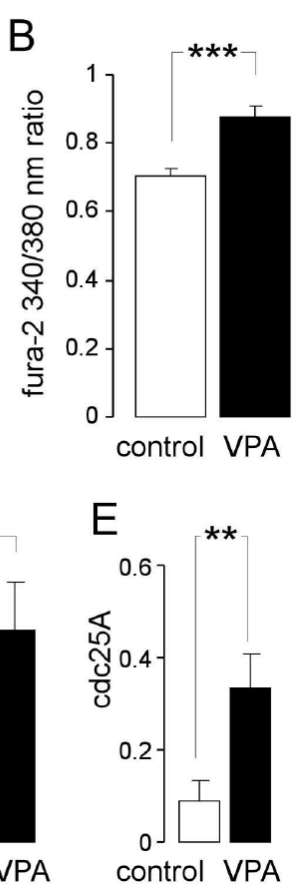

$\mathrm{H}$

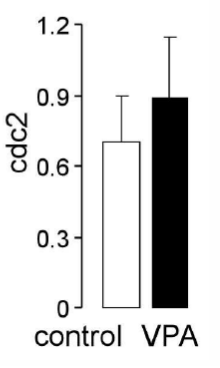

free medium for colony formation. In neither cell line, VPA modified radiosensitivity (Fig. 4A-C, left and right). In U251 and U-87MG but not in T98G cells VPA lowered the plating efficiency by some $20 \%$ (Fig. 4A-C, middle). Combined, these data suggest that VPA may impair clonogenic survival and slow-down cell cycle progression. VPA, however, does not seem to interfere with the stress response of glioblastoma cell lines following cell injury by ionizing radiation.

Finally, VPA effects on glioblastoma cell physiology were characterized. $\mathrm{Ca}^{2+}$ signaling has been demonstrated to stimulate $\mathrm{BK} \mathrm{K}^{+}$channel activity in glioblastoma cells [37]. Cell volume changes and electrosignaling by $\mathrm{BK} \mathrm{K}^{+}$channels, in turn, have been identified as key regulators of glioblastoma cell migration $[37,38]$. Therefore, VPA-dependent changes in BK $\mathrm{K}^{+}$channel activity and transfilter chemotaxis were assessed in T98G and U251 cell lines by patch-clamp on-cell recording (Fig. 5A-G) and by the use of a modified Boyden chamber (Fig. $5 \mathrm{H}, \mathrm{I})$, respectively.

Acute administration of VPA $(750 \mu \mathrm{M})$ stimulated outward current transitions with large unitary conductance in T98G and U251 cells (Fig. 5B, C, left and middle) that were blocked by the $\mathrm{BK} \mathrm{K}^{+}$channel-specific inhibitor paxilline (Fig. 5B, C, right). These VPAstimulated current transitions generated in both glioblastoma cell lines an outwardly rectifying macroscopic on-cell current at depolarized voltages (Fig. 5D, F) which gave rise to a significant increase in membrane conductance (Fig. 5E, G). Large unitary conductance, paxilline sensitivity, and voltage-dependent activation that results in outward rectification of 

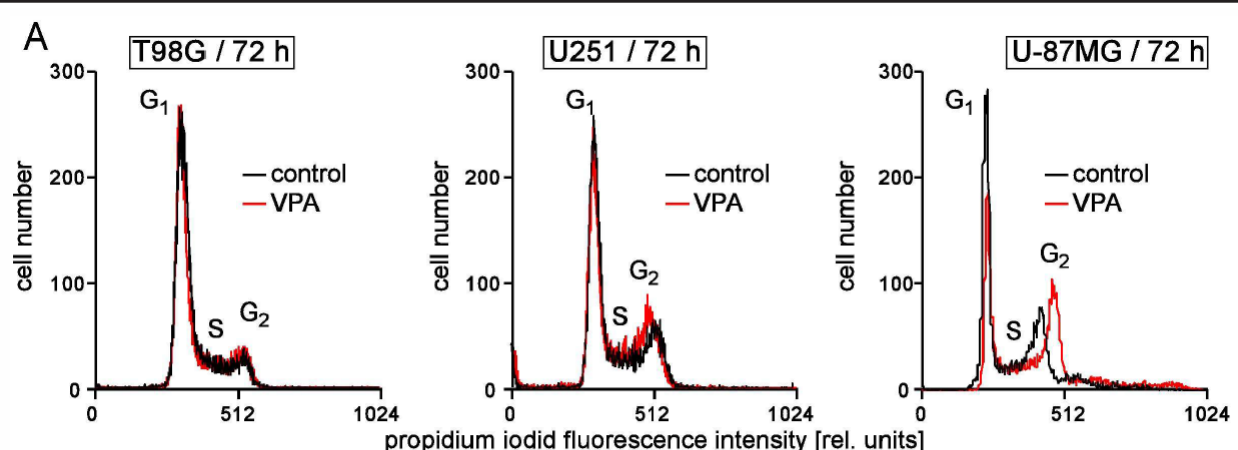

B T98G/48 h

propidium iodid fluorescence intensity [rel. units]

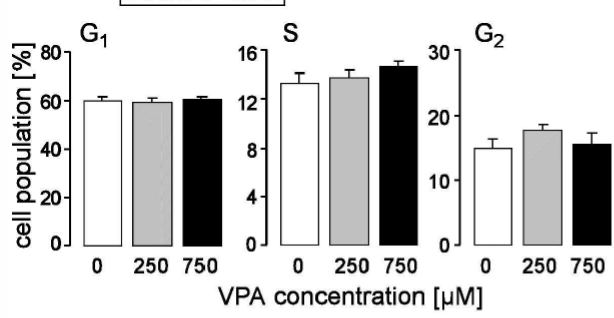

E T98G/72h
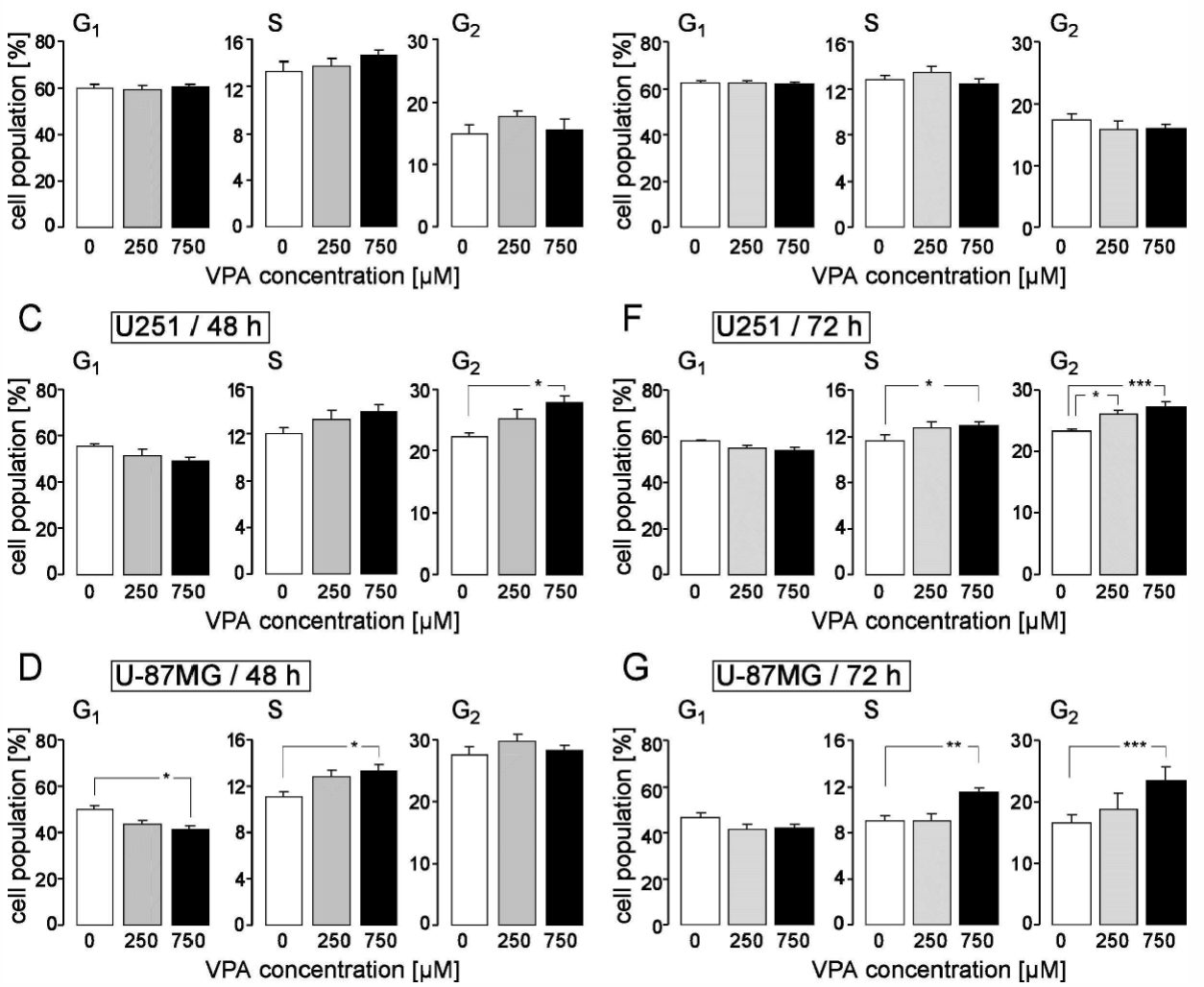

Fig. 3. VPA induces $S$ phase and $G_{2} / M$ cell cycle arrest in U251 and U-87MG but not in T98G glioblastoma cells. A. Histograms of propidium iodide-stained T89G (left), U251 (middle) and U-87MG cells (right) recorded by flow cytometry (Nicoletti protocol) after $72 \mathrm{~h}$ treatment with $0 \mu \mathrm{M}$ (control, black) or $750 \mu \mathrm{M}$ VPA (red). B-G. Mean percentage ( $\mathrm{n}=8$ 8-9) of T98G (B, E), U251 (C, F) and U-87MG (D, G) glioblastoma cells which resided in $\mathrm{G}_{1}$ (left), $\mathrm{S}$ (middle) or $\mathrm{G}_{2}$ (right) phase of cell cycle after $48 \mathrm{~h}$ (B-D) or $72 \mathrm{~h}$ (E-G) treatment with $0 \mu \mathrm{M}$ (open bars), $250 \mu \mathrm{M}$ (grey bars), or $750 \mu \mathrm{M}$ VPA (black bars).

the generated currents are typical features of $\mathrm{BK} \mathrm{K}^{+}$channels [38] indicating VPA-stimulated $\mathrm{BK} \mathrm{K}{ }^{+}$channel activation.

Elevated $\mathrm{BK} \mathrm{K}^{+}$channel activity was paralleled by a VPA $(750 \mu \mathrm{M})$-stimulated acceleration of transfilter chemotaxis in T98G cells triggered by a 1\%-to-5\% FBS gradient (Fig. 5H). Notably, in U251 cells VPA $(750 \mu \mathrm{M})$ exerted comparable similar stimulatory effects on transfilter chemotaxis cells only upon a $5 \mathrm{~h}$ to $48 \mathrm{~h}$ pretreatment with VPA (Fig. 5I). In summary, these experiments on human glioblastoma cell lines suggest that VPA may stimulate electrosignaling and migration of human glioblastoma cells.

\section{KARGER}


Fig. 4. VPA mitigates the plating efficiency of U251 and U-87MG but not of T98G glioblastoma cells without interfering with radioresitance. A, B, C. Mean survival fraction $(n=6)$ plotted against the radiation dose of T98G (A), U251 (B), and U87MG cells (C). Cells were pre-incubated (1 h), irradiated, and post-incubated $(24 \mathrm{~h})$ in the absence (open circles, black) or presence of VPA (750 $\mu \mathrm{M}$, red triangles) before plating in inhibitor-free medium (left) for colony formation (delayed plating colony formation assay). The plots on the middle and right show the mean ( $\mathrm{n}=12-24)$ plating efficiencies (middle) and survival fractions upon irradiation with $2 \mathrm{~Gy}$ ( $\mathrm{SF}_{2 \mathrm{~Gy}}$, right), respectively, for all three glioblastoma cell lines. Plating efficiencies and $\mathrm{SF}_{2 \mathrm{~Gy}}$ were determined in the absence (open bars) or presence of VPA $(750 \mu \mathrm{M}$, closed bars).
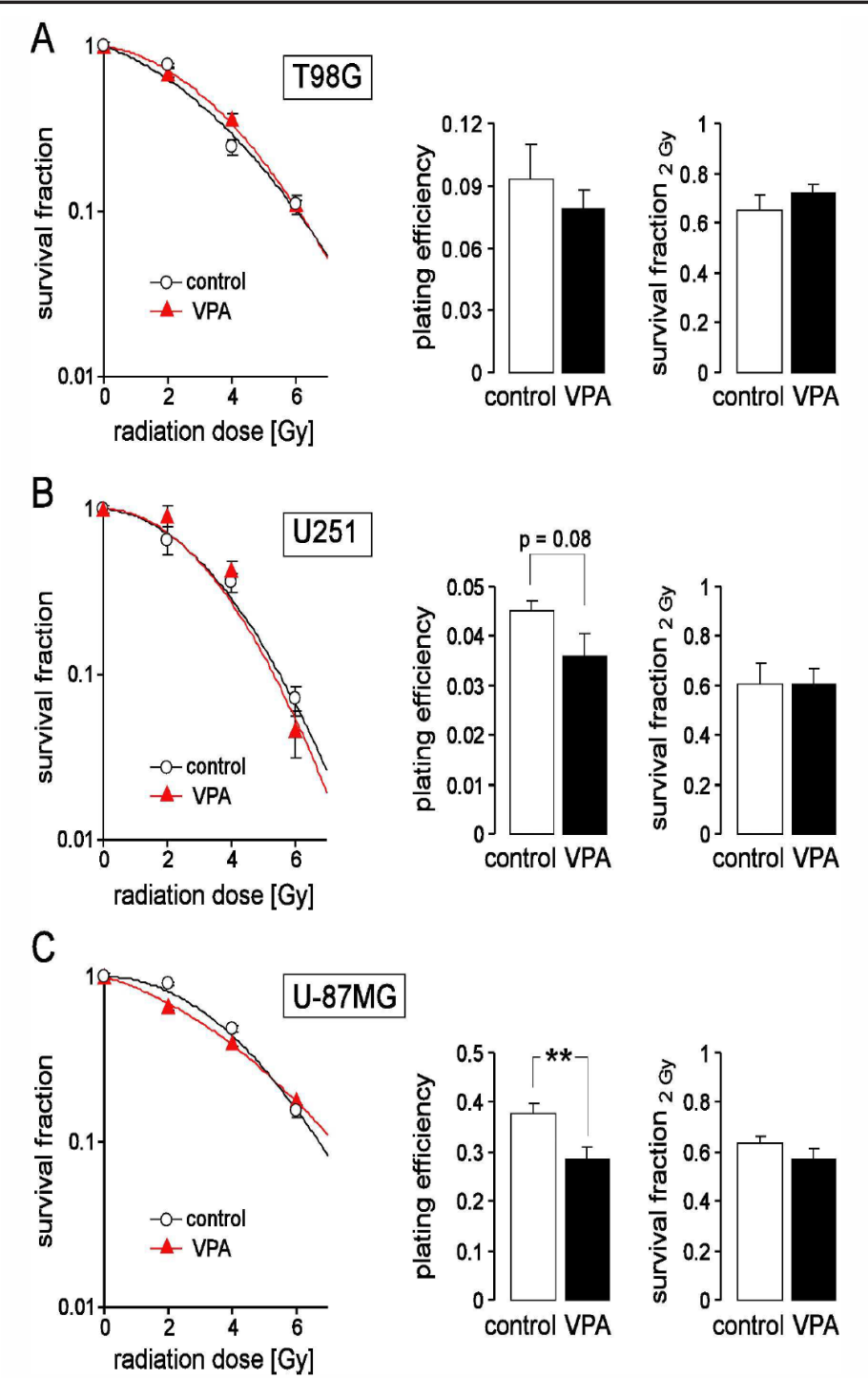

To test possible VPA effects on glioblastoma radio- and chemosensitivity in an experimental setting that resembles more the clinical situation, we grew primary spheroids from glioblastoma resectates (LK-XI, LK-XII, LK-XIII) in FBS-free stem cell medium. In these spheroids the minimal number of cells required to sustain the primary culture as a measure of clonogenicity was determined in the continuous presence of temozolomide in dependence on fractionated irradiation ( $5 \times 0$ Gy or $5 \times 2$ Gy) and VPA $(0$ or $750 \mu \mathrm{M})$ by pre-plating limited dilution assay (Fig. 6A, B). According to the Stupp protocol [2], glioblastoma patients are treated with $75 \mathrm{mg} / \mathrm{m}^{2}$ temozolomide concomitant to fractionated radiotherapy and with $150 \mathrm{mg} / \mathrm{m}^{2}$ for the subsequent maintenance chemotherapy. Patients receiving temozolomide $\left(150 \mathrm{mg} / \mathrm{m}^{2}\right)$ have been shown by intracerebral microdialysis to accumulate $1.2-3.4 \mathrm{~h}$ after drug administration maximal temozolomide concentrations in the brain interstitial fluid of $1.1-5.7 \mu \mathrm{M}$ [43]. Therefore, we chose a concentration of $5 \mu \mathrm{M}$ temozolomide added to the FBS-free medium for the limited dilution assay. As a result, minimal cell numbers required to sustain the primary cultures in the presence of temozolomide differed markedly between the individual glioblastoma cultures. In particular, the glioblastoma (LK-XII) specimen with epigenetic silencencing of the temozolomide resistance gene MGMT [44] (Fig. 6B, middle) required 5-10 times more cells to sustain clonogenic survival in the presence of temozolomide than the two other glioblastomas (LK-XI and LK-XIII) without MGMT promoter 

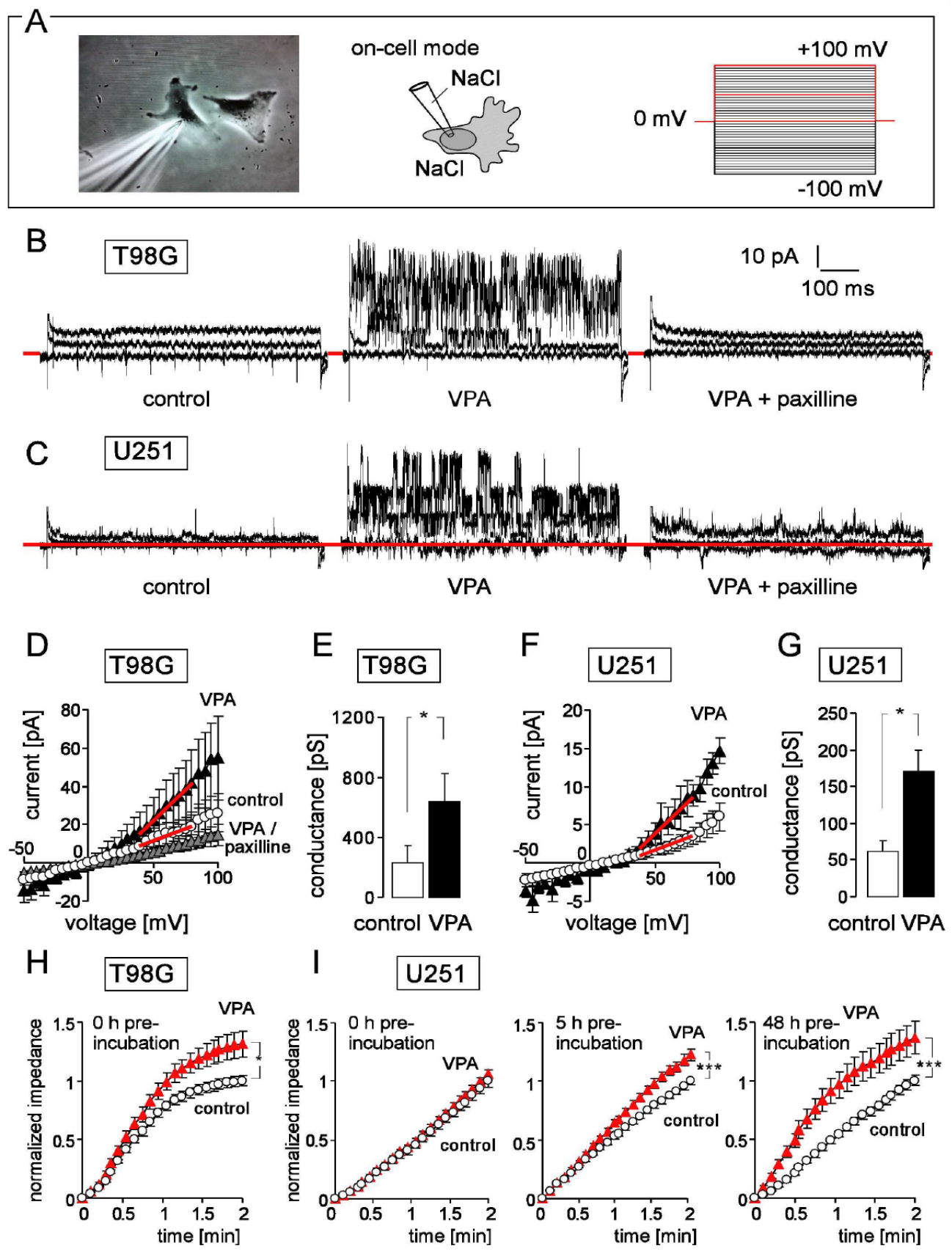

Fig. 5. VPA induces activation of $\mathrm{BK} \mathrm{K}{ }^{+}$channels and transfilter migration of T98G and U251 glioblastoma cells. A. On-cell patch-clamp recording of glioblastoma cells (left), recording conditions (middle), and applied voltage pulse protocol (right). B, C. On-cell current tracings from T98G (B) and U251 (C) glioblastoma cells cell before (left) and during application of VPA (750 $\mu \mathrm{M}$, middle) and additional BK inhibition via paxilline $(5 \mu \mathrm{M}$, right). Only voltage steps to $0,+50$, and $+100 \mathrm{mV}$ are shown. $\mathrm{D}$, F. Current/voltage-relationships of the mean ( $n=4-6)$ macroscopic on-cell currents of T98G (D) and U251 cells (F) as recorded in (B, C). E, G. Mean ( \pm SE) normalized conductance calculated for T89G (E) and U251 (G) before (open bars) and during administration of VPA (closed bars, data from D, F). H, I. Mean ( $\mathrm{n}=20-24)$ impedance (normalized to the 2 $\mathrm{h}$ values of the control) as a measure of transfilter migration along an 1\%-to-5\% FBS gradient recorded in T98G (H) and U251 (I) glioblastoma cells in the absence (control, open circle) or presence of VPA (750 $\mu \mathrm{M}$, red triangles). In some U251 experiments, migration in the presence of VPA was preceded by $5 \mathrm{~h}$ (B, middle) or $48 \mathrm{~h}$ (right) pre-incubation with VPA $(750 \mu \mathrm{M})$. 
Fig. 6. VPA fails to decrease clonogenic survival and to radiosensitize primary glioblastoma spheroids treated with temozolomide irrespectively of epigenetic MGMT downregulation. A. Light micrographs of sequential cell dilutions derived from mechanical dissociated primary glioblastoma spheroids grown for up to 50 days in serum-free stem cell medium in the presence of temozolomide $(5 \mu \mathrm{M})$ and either $0 \mu \mathrm{M}\left(1^{\text {st }}\right.$ and $3^{\text {rd }}$ line $)$ or $750 \mu \mathrm{M}$ VPA $\left(2^{\text {nd }}\right.$ and $4^{\text {th }}$ line $)$. Cells were fractionated irradiated on days 1-5 with a total dose of 0 Gy $\left(1^{\text {st }}\right.$ and $2^{\text {nd }}$ line $)$ or $10 \mathrm{~Gy}\left(3^{\text {rd }}\right.$ and $4^{\text {th }}$ line $)$. B. Mean ( $\pm \mathrm{SE}, \mathrm{n}=4$ ) minimal cell number to sustain the culture upon
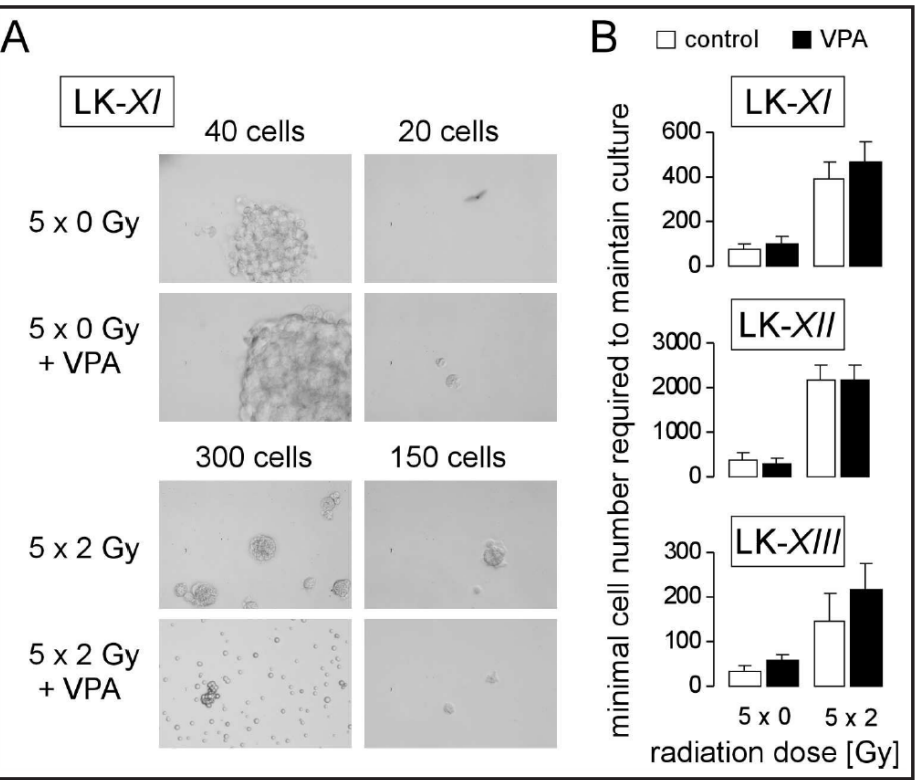
treatment with temozolomide $(5 \mu \mathrm{M})$ combined with either $0 \mu \mathrm{M}$ (open bars) or $750 \mu \mathrm{M}$ VPA (closed bars) and $5 \times 0$ Gy $\left(1^{\text {st }}\right.$ and $2^{\text {nd }}$ bars $)$ or $5 \times 2$ Gy ( $3^{\text {rd }}$ and $4^{\text {th }}$ bars $)$ fractionated irradiation. Shown are a MGMT promoter-methylated, supposed temozolomide-sensitive (LK-XII) and two MGMT promoter-unmethylated, supposed temozolomide-resistant primary spheroid cultures (LK-XI and LK-XIII).

methylation (Fig. 6B, top and bottom). Fractionated irradiation (5 $22 \mathrm{~Gy}$ ) decreased in all three glioblastoma cultures the clonogenic survival to about $20 \%$ of the non-irradiated cells (i.e., 5 times more cells were required to sustain the culture (Fig. 6B, open bars). Importantly, VPA $(750 \mu \mathrm{M})$ had no (LK-XII) or only very little and insignificant (LK-XI and LK-XIII) radio-/ chemosensitizing effects on clonogenic survival Fig. 6B, compare open with closed bars). Hence, these experiments on primary spheroids confirmed in a more clinically relevant setting the low VPA effects observed in the experiments on human glioblastoma cell lines described above.

\section{Discussion}

Valproic acid is an approved drug for the treatment of epileptic seizures but also off-label prescribed against migraine, depression, anxiety, psychotic disorders, alcohol withdrawal and dependence, dementia associated agitation, and borderline personality disorders $[45,46]$. During chronic oral treatment with $15-20 \mathrm{mg} / \mathrm{kg}$ VPA per day, epilepsia patients accumulate total plasma concentrations in the range of 0.3-0.7 $\mathrm{mM}$ (for review see [4]). In human beings, a high fraction of VPA binds to serum albumin. As a consequence, lower VPA concentrations of around $40-200 \mu \mathrm{M}$ at a daily VPA treatment of $15-20 \mathrm{mg} / \mathrm{kg}$ are observed in the brain indicating VPA brain/plasma ratios in the range of 0.07 to 0.28 . (for review see [4]). A dose escalation study in glioma patients defined $60 \mathrm{mg} / \mathrm{kg}$ VPA per day as maximal tolerable dose which gave rise to median plasma concentrations of about $0.85 \mathrm{mM}$ and a maximal plasma concentration not exceeding $1.4 \mathrm{mM}$ [47]. Taking the highest estimated brain/plasma ratio of 0.28 [4] as a basis, this translates to a maximal VPA concentration in the brain of $400 \mu \mathrm{M}$ under dose-escalation. Combined, this suggests a "therapeutic", i.e., anticonvulsive VPA concentration of $\leq 200 \mu \mathrm{M}$ in the brain which maximally can be doubled by dose escalation. This further suggests that preclinical studies applying VPA concentrations of $1 \mathrm{mM}$ or above most probably do no more mirror the clinical situations especially when the in vitro experiments were done under serum-free experimental conditions where the total equals the free, i.e., effective VPA concentration. 
VPA in the present in vitro study did not impair metabolic NAD(P)H formation of human U-87MG, T98G and U251 glioblastoma cells at concentrations of $<800 \mu \mathrm{M}$ (see Fig. 1). In addition, VPA at a concentration of $750 \mu \mathrm{M}$ did not radiosensitize the three human glioblastoma cell lines and three primary glioblastoma spheroid cultures studied in delayed plating colony formation assays and pre-plating limited dilution assays, respectively. These results were unexpected in light of the reported chromatin remodeling action of VPA [18, 48$50]$ and contradictory to previous in vitro studies [10-15, 17, 48, 51, 52] which clearly show VPA-induced cell death or radio- or chemosensitization in cancer cells including glioma. Unlike the present work, VPA concentrations of 1-5 mM [52], 1.5-2 mM [10], 1-5 mM [51], 2.5-5 mM [11], 1.5-3 mM [12], 1-15 mM [13], 2-16 mM [14], $7.5 \mathrm{mM}$ [18], $2 \mathrm{mM}$ [19], 5-20 $\mathrm{mM}$ [53], 1-10 mM [21], or $4.8 \mathrm{mM}$ [22] were applied in these studies.

In particular, in delayed- or pre-plating colony formation assays VPA concentrations of $2.5 \mathrm{mM}, 1.5 \mathrm{mM}$, and $3 \mathrm{mM}$ have been reported to radiosensitize T98G cells $(24 \mathrm{~h}$ and 48 $\mathrm{h}$ VPA pre-incubation, VPA co-incubation during irradiation, and VPA-free post-incubation [11]), U251 cells (30 h VPA pre-incubation and VPA co-incubation during irradiation, and VPA post-incubation [10]), and U-87MG cells (18 h VPA pre- incubation, VPA co-incubation during irradiation, VPA-free post-incubation [12]), respectively. In the present study, VPA $(750 \mu \mathrm{M})$ failed to radiosensitize T98G, U251 and U-87MG in delayed plating colony formation assays ( $1 \mathrm{~h}$ VPA-pre-incubation, VPA co-incubation during irradiation, and $24 \mathrm{~h}$ VPA postincubation). Likewise, in the present experiments on primary glioblastoma spheroid cultures subjected to fractionated irradiation ( $5 \times 0$ Gy or $5 \times 2$ Gy) and temozolomide ( $5 \mu \mathrm{M})$, VPA $(750 \mu \mathrm{M})$ neither impaired clonogenic survival nor radiosensitized the cells while a previous study using higher VPA concentrations (1-15 mM) in a similar experimental setting (primary glioblastoma cultures, irradiation, temozolomide) reported VPA-mediated inhibition of cell viability by MTT assay [13].

These apparent discrepancies between the previous reports and the present study might result from the different protocols applied. They might also hint to a difference in histone hyperacetylation status. The glioblastoma data base of the The Cancer Genome Atlas suggests that individual glioblastoma specimens differ markedly in their pattern of HDAC isoform expression (see Fig. 7A). In particular, glioblastoma specimens, primary cultures and cell lines reportedly over-express histone deacetylases HDAC1, $-3,-6,-9$ and the class III histone deacetylase SIRT2 when compared to normal brain tissue. Importantly, HDAC3, -9 , and SIRT2 expression levels in the tumor have been associated with poor survival of the glioblastoma patients (for review see [6]). Since VPA has been shown to inhibit class-I and -II HDACs with $\mathrm{IC}_{50}$ values ranging from 150-700 $\mu \mathrm{M}$ for HDAC1 [54, 55], 1.0-5.5 mM [54, 55] for HDAC3, and >20 mM for HDAC6 [55], respectively (also see Fig. 7A), one might speculate that small variation of the VPA concentration in this range may result in significant changes of HDAC inhibition. Therefore, the higher VPA concentrations used in the previous

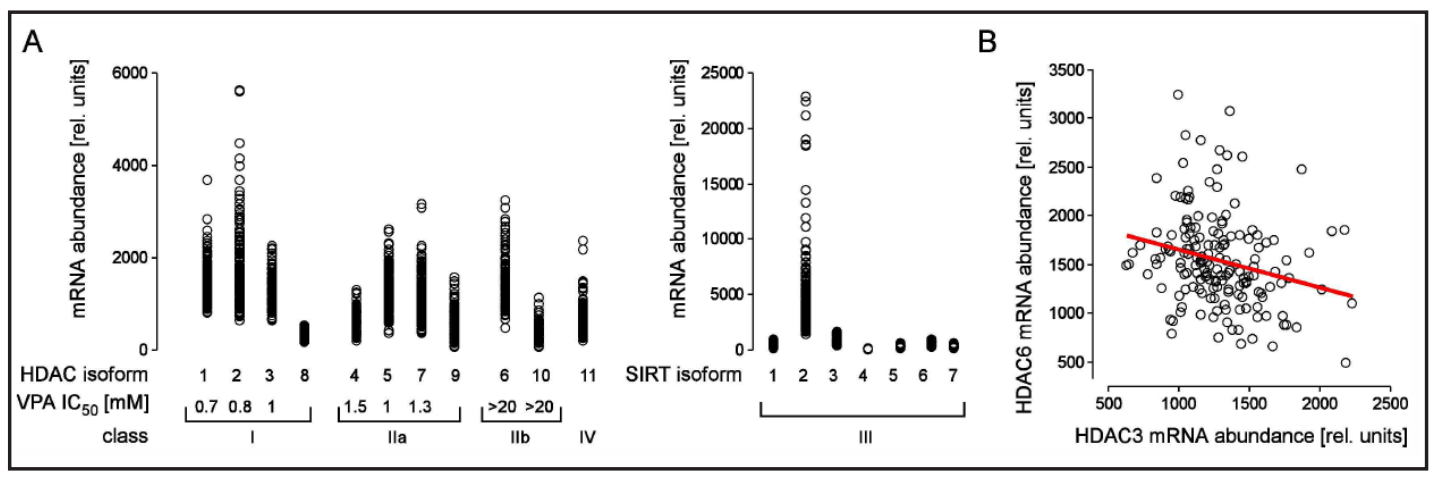

Fig. 7. Individual glioblastoma specimens show different patterns of histone deacetylase (HDAC) isoform expression. A, B. Abundances of mRNAs encoding class-I, -IIa, -IIb, -III and -IV HDAC in human glioblastoma specimens $(n=166)$. Given are RNA Seq data from the glioblastoma database of The Cancer Genome Atlas. The lower numbers in (A), left, indicate the $\mathrm{IC}_{50}$ values for HDAC inhibition by VPA (IC ${ }_{50}$ values from: [55]). 
in vitro studies [10-12] might have induced radiosensitizing histone hyperacetylation while the lower VPA concentration applied in the present study did not. If so, VPA concentrations of $40-200 \mu \mathrm{M}(400 \mu \mathrm{M})$ usually accumulating in the brain of epilepsy patients (see above) would be expected to promote radiosensitizing histone hyperacetylation only if an individual glioblastoma expresses a high ratio between VPA-sensitive (e.g., HDAC1) and -insensitive (e.g., HDAC6) HDACs. This ratio may differ markedly between individual glioblastoma specimens as shown for the mRNA abundances of HDAC3 and HDAC6 in Fig. 7B. In contrast to human cells, VPA-induced radiosensitization at concentrations as low as $600 \mu \mathrm{M}$ has been demonstrated in C6 rat glioma cells by colony formation assay $[10,51]$ which might hint to expression of more VPA-sensitive histone deacetylase isoforms in rodent cells.

Finally, one have to bear in mind that VPA is an organic acid with a $\mathrm{pK}_{\mathrm{a}}$ value of 4.56 [4] deducing that $0.14 \%$ of VPA exists as protonated uncharged acid (H-VPA) at physiological $\mathrm{pH}$. Since H-VPA is highly lipophilic (log octane/water partition coefficient $=2.29$ ), H-VPA can freely cross the plasma membrane and acidifies the cytoplasm. Therefore, it can be assumed that reported in vitro experiments using several millimolar VPA concentrations confer unspecific cellular pH stress and - if not controlled properly - additional physiologically relevant osmotic stress which might impact on radiation and temozolomide sensitivity and trigger cellular stress responses that are different from the pharmacology of VPA in the clinical situation.

Along those lines, in preclinical ectopic glioblastoma mouse models, treating irradiated (single fraction of 4 Gy [10] or 4 fractions of 3 Gy [12]) human xenografts with VPA (daily i.p. administration of $2 \times 150 \mathrm{mg} / \mathrm{kg}$ over 3 [10] or 6 days [12]) delayed tumor growth when compared to irradiation alone while VPA-treatment of unirradiated tumors had no effect. Pharmacokinetics differ markedly between mouse and human beings. For instance, only $12 \%$ of VPA in mouse plasma are bound to plasma protein while $80-95 \%$ do so in human plasma [4]. Moreover, the VPA dose (300 mg/kg i.p. per day) applied in the in vivo studies was in the order of magnitude of the $\mathrm{LD}_{50}\left(\mathrm{LD}_{50}=470 \mathrm{mg} / \mathrm{kg}\right.$ BW for i.p. administration in mice, Material Safety Data Sheet, Santa Cruz Biotechnology, Inc., Santa Cruz, CA). Therefore, these mouse studies most probably applied much higher effective VPA concentrations than those achieved in the clinical situation in glioblastoma patients even upon dose escalation.

Likewise, a recent study on human U-87MG glioblastoma xenografts grown in chicken embryos which reported VPA-mediated impairment of angiogenesis and mesenchyme invasion by the tumor, applied VPA concentrations of 4 and $8 \mathrm{mM}$ [56]. Notably, a further in vivo study transplanting primary human WK1 glioblastoma cells pre-treated with radiation and/or temozolomide and/or VPA (1 mM under serum-free conditions) orthotopically in mice observed a prolonged survival as compared to the control group (challenged with vehicle-treated WK1 cells) only in mice inoculated with radiation/VPA co-treated cells or radiation/temozolomide/VPA triple-treated cells [13]. Although suggestive of a VPAmediated radiosensitization, it has to be noted that this study [13] did not report significant longer mouse survival upon inoculation with VPA/radiation double-treated and VPA/ radiation/temozolomide triple-treated cells as compared to the survival of mice challenged with only radiation-treated and radiation/temozolomide co-treated cells, respectively.

Combined the previous in vitro and in vivo data indicate that VPA at a certain concentration may radiosensitize glioblastoma cells possibly by exceeding the threshold of relevant HDAC inhibition which results in radiosensitizing histone hyperacetylation. However, whether or not 'therapeutic' VPA concentration achieved in the clinical situation may reach this threshold might depend on the fractional expression of highly VPA-sensitive HDAC isoforms by the individual tumor. The present data on three glioblastoma cell lines and three primary glioblastoma spheroid cultures suggest that the percentage of such VPAsensitive tumors might be low.

The anticonvulsive action of VPA at 'therapeutic' concentrations is probably based on the direct interference of VPA with the glutamatergic, GABAergic and ion channel-mediated electrosignaling of excitable cells. Electrosignaling has been demonstrated to contribute to neoplastic transformation, malignant progression and therapy resistance of cancer cells (for

\section{KARGER}


review see [57]). In glioblastoma cells, radiation has been shown to induce electrosignaling (for review see [58]) that involves $\mathrm{Ca}^{2+}$-activated $\mathrm{BK} \mathrm{K}^{+}$channels promoting radiogenic hypermigration $[37,38]$ and $\mathrm{Ca}^{2+}$-activated $\mathrm{IK} \mathrm{K}^{+}$channels conferring radioresistance $[35$, 59] in particular in mesenchymal glioblastoma stem cells [60]. While having no effect on radioresistance in the present study, VPA $(750 \mu \mathrm{M})$ elicited $\mathrm{Ca}^{2+}$ signals in U251 and U-87MG cells that were paralleled by phosphorylation/degradation of the phosphatase cdc25A (a regulator of $\mathrm{G}_{1} / \mathrm{S}$ transition and S progression [61]) and stabilization of the phosphorylated, inactive form of the mitose promoting factor cdc2. In accordance with inactivation of cdc25A and cdc2, VPA $(750 \mu \mathrm{M})$ induced $S$ and $\mathrm{G}_{2} / \mathrm{M}$ cell cycle arrest, respectively, in U251 and U-87MG. Since these effects were accompanied by only a slightly decreased clonogenic survival, their impact on the potential therapeutic value of VPA is most probably negligible.

The VPA-evoked $\mathrm{Ca}^{2+}$ signals, on the other hand, stimulated in the present study the activity of BK K ${ }^{+}$channels in U251 cells. Surprisingly, VPA $(750 \mu \mathrm{M})$ induced BK K${ }^{+}$channel activity also in T98G cells in which VPA effects on neither $\mathrm{Ca}^{2+}$ signaling nor cell cycle were apparent. In accordance to the reported pro-migratory function of $\mathrm{BK} \mathrm{K}^{+}$channels $[37,38]$. VPA accelerated transfilter chemotaxis of U251 and T98G cells in the present study (U-87MG cells were not tested).

Combined, the present data do not suggest a radiosensitizing effect of VPA in glioblastoma cells in general at concentrations achieved in the clinical situation. On the contrary, the observed VPA-mediated acceleration of glioblastoma cell migration might hint to an adverse side effect of VPA, which in the worst case, might boost tumor spreading and brain infiltration.

\section{Acknowledgments}

LK was supported by the ICEPHA program of the University of Tübingen and the Robert-Bosch-Gesellschaft für Medizinische Forschung, Stuttgart. We thank Heidrun Faltin for excellent technical assistance.

\section{Disclosure Statement}

The authors declare no conflict of interest.

\section{References}

1 Stupp R, Mason WP, van den Bent MJ, Weller M, Fisher B, Taphoorn MJ, Belanger K, Brandes AA, Marosi C, Bogdahn U, Curschmann J, Janzer RC, Ludwin SK, Gorlia T, Allgeier A, Lacombe D, Cairncross JG, Eisenhauer E, Mirimanoff RO, European Organisation for R, Treatment of Cancer Brain T, Radiotherapy G, National Cancer Institute of Canada Clinical Trials G: Radiotherapy plus concomitant and adjuvant temozolomide for glioblastoma. N Engl J Med 2005;352:987-996.

-2 Stupp R, Hegi ME, Mason WP, van den Bent MJ, Taphoorn MJ, Janzer RC, Ludwin SK, Allgeier A, Fisher B, Belanger K, Hau P, Brandes AA, Gijtenbeek J, Marosi C, Vecht CJ, Mokhtari K, Wesseling P, Villa S, Eisenhauer E, Gorlia T, Weller M, Lacombe D, Cairncross JG, Mirimanoff RO, European Organisation for R, Treatment of Cancer Brain T, Radiation Oncology G, National Cancer Institute of Canada Clinical Trials G: Effects of radiotherapy with concomitant and adjuvant temozolomide versus radiotherapy alone on survival in glioblastoma in a randomised phase III study: 5-year analysis of the EORTC-NCIC trial. Lancet Oncol 2009;10:459-466.

3 Prakash O, Lukiw WJ, Peruzzi F, Reiss K, Musto AE: Gliomas and seizures. Med Hypotheses 2012;79:622626.

4 Loscher W: Valproate: A reappraisal of its pharmacodynamic properties and mechanisms of action. Prog Neurobiol 1999;58:31-59. 


\section{Cellular Physiology Cell Physiol Biochem 2017;44:1591-1605 \begin{tabular}{ll|l} 
and Biochemistry & $\begin{array}{l}\text { DOI: 10.1159/000485753 } \\
\text { Published online: December 06, 2017 }\end{array}$ & $\begin{array}{l}\text { @ 2017 The Author(s). Published by S. Karger AG, Basel } \\
\text { www.karger.com/cpb }\end{array}$ \\
\hline
\end{tabular}}

Eckert et al.: VPA in Glioma

5 Chateauvieux S, Morceau F, Dicato M, Diederich M: Molecular and therapeutic potential and toxicity of valproic acid. J Biomed Biotechnol 2010;2010.

6 Lee DH, Ryu HW, Won HR, Kwon SH: Advances in epigenetic glioblastoma therapy. Oncotarget 2017;8:18577-18589.

7 Eikel D, Lampen A, Nau H: Teratogenic effects mediated by inhibition of histone deacetylases: Evidence from quantitative structure activity relationships of 20 valproic acid derivatives. Chem Res Toxicol 2006;19:272-278.

$>8$ Ornoy A: Valproic acid in pregnancy: How much are we endangering the embryo and fetus? Reprod Toxicol 2009;28:1-10.

-9 Groselj B, Sharma NL, Hamdy FC, Kerr M, Kiltie AE: Histone deacetylase inhibitors as radiosensitisers: Effects on DNA damage signalling and repair. Br J Cancer 2013;108:748-754.

10 Camphausen K, Cerna D, Scott T, Sproull M, Burgan WE, Cerra MA, Fine H, Tofilon PJ: Enhancement of in vitro and in vivo tumor cell radiosensitivity by valproic acid. Int J Cancer 2005;114:380-386.

-11 Van Nifterik KA, Van den Berg J, Slotman BJ, Lafleur MV, Sminia P, Stalpers LJ: Valproic acid sensitizes human glioma cells for temozolomide and gamma-radiation. J Neurooncol 2012;107:61-67.

12 Chie EK, Shin JH, Kim JH, Kim HJ, Kim IA, Kim IH: In vitro and in vivo radiosensitizing effect of valproic acid on fractionated irradiation. Cancer Res Treat 2015;47:527-533.

13 Hosein AN, Lim YC, Day B, Stringer B, Rose S, Head R, Cosgrove L, Sminia P, Fay M, Martin JH: The effect of valproic acid in combination with irradiation and temozolomide on primary human glioblastoma cells. J Neurooncol 2015;122:263-271.

14 Zhang C, Liu S, Yuan X, Hu Z, Li H, Wu M, Yuan J, Zhao Z, Su J, Wang X, Liao Y, Liu Q: Valproic acid promotes human glioma U87 cells apoptosis and inhibits glycogen synthase kinase-3beta through ERK/AKT signaling. Cell Physiol Biochem 2016;39:2173-2185.

15 Zhang H, Zhang W, Zhou Y, Jiang Y, Li S: Dual functional mesoporous silicon nanoparticles enhance the radiosensitivity of VPA in glioblastoma. Transl Oncol 2017;10:229-240.

16 Detich N, Bovenzi V, Szyf M: Valproate induces replication-independent active DNA demethylation. J Biol Chem 2003;278:27586-27592.

17 Ryu CH, Yoon WS, Park KY, Kim SM, Lim JY, Woo JS, Jeong CH, Hou Y, Jeun SS: Valproic acid downregulates the expression of MGMT and sensitizes temozolomide-resistant glioma cells. J Biomed Biotechnol 2012;2012:987495.

18 Hoja S, Schulze M, Rehli M, Proescholdt M, Herold-Mende C, Hau P, Riemenschneider MJ: Molecular dissection of the valproic acid effects on glioma cells. Oncotarget 2016;7:62989-63002.

19 Riva G, Butta V, Cilibrasi C, Baronchelli S, Redaelli S, Dalpra L, Lavitrano M, Bentivegna A: Epigenetic targeting of glioma stem cells: Short-term and long-term treatments with valproic acid modulate DNA methylation and differentiation behavior, but not temozolomide sensitivity. Oncol Rep 2016;35:2811-2824.

20 Gefroh-Grimes HA, Gidal BE: Antiepileptic drugs in patients with malignant brain tumor: Beyond seizures and pharmacokinetics. Acta Neurol Scand 2016;133:4-16.

-21 Kawashima N, Nishimiya Y, Takahata S, Nakayama KI: Induction of glycosphingolipid gm3 expression by valproic acid suppresses cancer cell growth. J Biol Chem 2016;291:21424-21433.

22 Raja E, Komuro A, Tanabe R, Sakai S, Ino Y, Saito N, Todo T, Morikawa M, Aburatani H, Koinuma D, Iwata C, Miyazono K: Bone morphogenetic protein signaling mediated by ALK-2 and DLX2 regulates apoptosis in glioma-initiating cells. Oncogene 2017;36:4963-4974.

-23 Proske J, Walter L, Bumes E, Hutterer M, Vollmann-Zwerenz A, Eyupoglu IY, Savaskan NE, Seliger C, Hau P, Uhl M: Adaptive immune response to and survival effect of temozolomide- and valproic acid-induced autophagy in glioblastoma. Anticancer Res 2016;36:899-905.

24 Watanabe S, Kuwabara Y, Suehiro S, Yamashita D, Tanaka M, Tanaka A, Ohue S, Araki H: Valproic acid reduces hair loss and improves survival in patients receiving temozolomide-based radiation therapy for high-grade glioma. Eur J Clin Pharmacol 2017;73:357-363.

-25 Weller M, Gorlia T, Cairncross JG, van den Bent MJ, Mason W, Belanger K, Brandes AA, Bogdahn U, Macdonald DR, Forsyth P, Rossetti AO, Lacombe D, Mirimanoff RO, Vecht CJ, Stupp R: Prolonged survival with valproic acid use in the EORTC/NCIC temozolomide trial for glioblastoma. Neurology 2011;77:11561164. 


\section{Cellular Physiology Cell Physiol Biochem 2017;44:1591-1605 \begin{tabular}{l|l|l}
\hline and Biochemistry 10.1159/000485753 & $\begin{array}{l}\text { C } 2017 \text { The Author(s). Published by S. Karger AG, Basel } \\
\text { www.karger.com/cpb }\end{array}$ \\
\hline
\end{tabular}}

Eckert et al.: VPA in Glioma

-26 Yuan Y, Xiang W, Qing M, Yanhui L, Jiewen L, Yunhe M: Survival analysis for valproic acid use in adult glioblastoma multiforme: A meta-analysis of individual patient data and a systematic review. Seizure 2014;23:830-835.

27 Oberndorfer S, Piribauer M, Marosi C, Lahrmann H, Hitzenberger P, Grisold W: P450 enzyme inducing and non-enzyme inducing antiepileptics in glioblastoma patients treated with standard chemotherapy. J Neurooncol 2005;72:255-260.

-28 Barker CA, Bishop AJ, Chang M, Beal K, Chan TA: Valproic acid use during radiation therapy for glioblastoma associated with improved survival. Int J Radiat Oncol Biol Phys 2013;86:504-509.

-29 Kerkhof M, Dielemans JC, van Breemen MS, Zwinkels H, Walchenbach R, Taphoorn MJ, Vecht CJ: Effect of valproic acid on seizure control and on survival in patients with glioblastoma multiforme. Neuro Oncol 2013;15:961-967.

30 Guthrie GD, Eljamel S: Impact of particular antiepileptic drugs on the survival of patients with glioblastoma multiforme. J Neurosurg 2013;118:859-865.

31 Krauze AV, Myrehaug SD, Chang MG, Holdford DJ, Smith S, Shih J, Tofilon PJ, Fine HA, Camphausen K: A phase 2 study of concurrent radiation therapy, temozolomide, and the histone deacetylase inhibitor valproic acid for patients with glioblastoma. Int J Radiat Oncol Biol Phys 2015;92:986-992.

-32 Happold C, Gorlia T, Chinot O, Gilbert MR, Nabors LB, Wick W, Pugh SL, Hegi M, Cloughesy T, Roth P, Reardon DA, Perry JR, Mehta MP, Stupp R, Weller M: Does valproic acid or levetiracetam improve survival in glioblastoma? A pooled analysis of prospective clinical trials in newly diagnosed glioblastoma. J Clin Oncol 2016;34:731-9.

-33 Berendsen S, Varkila M, Kroonen J, Seute T, Snijders TJ, Kauw F, Spliet WG, Willems M, Poulet C, Broekman ML, Bours V, Robe PA: Prognostic relevance of epilepsy at presentation in glioblastoma patients. Neuro Oncol 2016;18:700-706

-34 Fay MF, Head R, Sminia P, Dowson N, Cosgrove L, Rose SE, Martin JH: Valproate in adjuvant glioblastoma treatment. J Clin Oncol 2016;34:3105-3107.

35 Stegen B, Klumpp L, Misovic M, Edalat L, Eckert M, Klumpp D, Ruth P, Huber SM: K+ channel signaling in irradiated tumor cells. Eur Biophys J 2016;45:585-598.

-36 Wolfsperger F, Hogh-Binder S, Schittenhelm J, Psaras T, Ritter V, Bornes L, Huber SM, Jendrossek V, Rudner J: Deubiquitylating enzymeUSP9x regulates radiosensitivity in glioblastoma cells byMcl-1-dependent and -independent mechanisms Cell Death Dis 2016;7:e2039.

-37 Edalat L, Stegen B, Klumpp L, Haehl E, Schilbach K, Lukowski R, Kühnle M, Bernhardt G, Buschauer A, Zips D, Ruth P, Huber SM: BK K ${ }^{+}$channel blockade inhibits radiation-induced migration/brain infiltration of glioblastoma cells. Oncotarget 2016;714259-14278

-38 Steinle M, Palme D, Misovic M, Rudner J, Dittmann K, Lukowski R, Ruth P, Huber SM: Ionizing radiation induces migration of glioblastoma cells by activating BK K+ channels. Radiother Oncol 2011;101:122-126.

39 Heise N, Palme D, Misovic M, Koka S, Rudner J, Lang F, Salih HR, Huber SM, Henke G: Non-selective cation channel-mediated $\mathrm{Ca}^{2+}$-entry and activation of $\mathrm{Ca}^{2+} /$ calmodulin-dependent kinase II contribute to $\mathrm{G}_{2} / \mathrm{M}$ cell cycle arrest and survival of irradiated leukemia cells. Cell Physiol Biochem 2010;26:597-608.

-40 Palme D, Misovic M, Schmid E, Klumpp D, Salih HR, Rudner J, Huber SM: K 3.4 potassium channel-mediated electrosignaling controls cell cycle and survival of irradiated leukemia cells. Pflugers Arch 2013;465:12091221.

41 Klumpp D, Frank SC, Klumpp L, Sezgin EC, Eckert M, Edalat L, Bastmeyer M, Zips D, Ruth P, Huber SM: TRPM8 is required for survival and radioresistance of glioblastoma cells. Oncotarget 2017;8:95896-95913.

-42 Klumpp D, Misovic M, Szteyn K, Shumilina E, Rudner J, Huber SM: Targeting TRPM2 channels impairs radiation-induced cell cycle arrest and fosters cell death of t cell leukemia cells in a Bcl-2-dependent manner. Oxidative Medicine and Cellular Longevity 2016;2016:8026702.

43 Portnow J, Badie B, Chen M, Liu A, Blanchard S, Synold TW: The neuropharmacokinetics of temozolomide in patients with resectable brain tumors: Potential implications for the current approach to chemoradiation. Clin Cancer Res 2009;15:7092-7098.

44 Hegi ME, Diserens AC, Gorlia T, Hamou MF, de Tribolet N, Weller M, Kros JM, Hainfellner JA, Mason W, Mariani L, Bromberg JE, Hau P, Mirimanoff RO, Cairncross JG, Janzer RC, Stupp R: MGMT gene silencing and benefit from temozolomide in glioblastoma. N Engl J Med 2005;352:997-1003.

45 Löscher W: Valproic acid. Mechanism of action; in Levy RH, Mattson RH, Meldrum BS, Perucca E (eds): Antiepileptic drugs. Philadelphia, Lippincott Williams \& Wilkins, 2002, pp 765-853. 


\section{Cellular Physiology Cell Physiol Biochem 2017;44:1591-1605 \begin{tabular}{l|l} 
DOI: 10.1159/000485753 & $\begin{array}{l}\text { O 2017 The Author(s). Published by S. Karger AG, Basel } \\
\text { www.karger.com/cpb }\end{array}$ \\
\hline
\end{tabular}}

46 Fleming J, Chetty M: Therapeutic monitoring of valproate in psychiatry: How far have we progressed? Clin Neuropharmacol 2006;29:350-360.

-47 Atmaca A, Al-Batran SE, Maurer A, Neumann A, Heinzel T, Hentsch B, Schwarz SE, Hovelmann S, Gottlicher M, Knuth A, Jager E: Valproic acid (VPA) in patients with refractory advanced cancer: A dose escalating phase Iclinical trial. Br J Cancer 2007;97:177-182.

-48 Shoji M, Ninomiya I, Makino I, Kinoshita J, Nakamura K, Oyama K, Nakagawara H, Fujita H, Tajima H, Takamura H, Kitagawa H, Fushida S, Harada S, Fujimura T, Ohta T: Valproic acid, a histone deacetylase inhibitor, enhances radiosensitivity in esophageal squamous cell carcinoma. Int J Oncol 2012;40:21402146.

-49 Bahna SG, Niles LP: Epigenetic induction of melatonin MT1 receptors by valproate: Neurotherapeutic implications. Eur Neuropsychopharmacol 2017;27:828-832.

50 Veronezi GM, Felisbino MB, Gatti MS, Mello ML, Vidal BC: DNA methylation changes in valproic acid-treated HeLa cells as assessed by image analysis, immunofluorescence and vibrational microspectroscopy. PLoS One 2017;12:e0170740.

51 Harikrishnan KN, Karagiannis TC, Chow MZ, El-Osta A: Effect of valproic acid on radiation-induced DNA damage in euchromatic and heterochromatic compartments. Cell Cycle 2008;7:468-476.

52 Leng Y, Wang J, Wang Z, Liao HM, Wei M, Leeds P, Chuang DM: Valproic acid and other HDAC inhibitors upregulate FGF21 gene expression and promote process elongation in glia by inhibiting HDACc2 and 3. Int J Neuropsychopharmacol 2016;19.

53 Cornago M, Garcia-Alberich C, Blasco-Angulo N, Vall-Llaura N, Nager M, Herreros J, Comella JX, Sanchis D, Llovera $\mathrm{M}$ : Histone deacetylase inhibitors promote glioma cell death by $\mathrm{G}_{2}$ checkpoint abrogation leading to mitotic catastrophe. Cell Death Dis 2014;5:e1435.

54 Huber K, Doyon G, Plaks J, Fyne E, Mellors JW, Sluis-Cremer N: Inhibitors of histone deacetylases: Correlation between isoform specificity and reactivation of HIV type 1 (HIV-1) from latently infected cells. J Biol Chem 2011;286:22211-22218.

55 Gurvich N, Tsygankova OM, Meinkoth JL, Klein PS: Histone deacetylase is a target of valproic acid-mediated cellular differentiation. Cancer Res 2004;64:1079-1086.

56 Kavaliauskaite D, Stakisaitis D, Martinkute J, Slekiene L, Kazlauskas A, Balnyte I, Lesauskaite V, Valanciute A: The effect of sodium valproate on the glioblastoma U87 cell line tumor development on the chicken embryo chorioallantoic membrane and on EZH2 and p53 expression. Biomed Res Int 2017;2017:6326053.

57 Huber SM: Oncochannels. Cell Calcium 2013;53:241-255.

58 Huber SM, Butz L, Stegen B, Klumpp D, Braun N, Ruth P, Eckert F: Ionizing radiation, ion transports, and radioresistance of cancer cells. Front Physiol 2013;4:212.

59 Stegen B, Butz L, Klumpp L, Zips D, Dittmann K, Ruth P, Huber SM: $\mathrm{Ca}^{2+}$-activated IK K+ channel blockade radiosensitizes glioblastoma cells. Mol Cancer Res 2015;13:1283-1295.

60 Klumpp L, Sezgin EC, Skardelly M, Eckert F, Huber SM: $\mathrm{K}_{\mathrm{Ca}} 3.1$ channels and glioblastoma: In vitro studies. Curr Neuropharmacol 2017. doi: 10.2174/1570159X15666170808115821.

-61 Shen T, Huang S: The role of cdc25a in the regulation of cell proliferation and apoptosis. Anticancer Agents Med Chem 2012;12:631-639. 